\title{
Purification and characterization of glucose-6-phosphate dehydrogenase from Aspergillus niger and Aspergillus nidulans
}

\author{
Lambert M. J. Wennekes, Theo Goosen, Peter J. M. van den Broek \\ and HENK W. J. VAN DEN BROEK*
}

Department of Genetics, Agricultural University, Dreijenlaan 2, 6703 HA Wageningen, The Netherlands

(Received 12 May 1993; revised 12 July 1993; accepted 21 July 1993)

\begin{abstract}
Glucose-6-phosphate dehydrogenase (G6PD; D-glucose 6-phosphate:NADP ${ }^{+}$oxidoreductase, EC 1.1 1. 19) has been purified from Aspergillus nidulans and Aspergillus niger by a combination of affinity and anion exchange chromatography. A 500-1000-fold purification was obtained and the final enzyme preparations were shown to be pure but not homogeneous. For both fungi the purified enzyme preparation gave two bands on native and denaturing gels. The catalytically active form is a multimer. The molecular mass of the monomers is 60 and $57 \mathrm{kDa}$ for $\boldsymbol{A}$. nidulans and 55 and $53 \mathrm{kDa}$ for $\boldsymbol{A}$. niger. Both enzymes exhibited strict specificity towards both substrates glucose 6-phosphate and NADP ${ }^{+}$. The $A$. nidulans and $A$. niger G6PD enzymes catalyse the conversion of glucose 6-phosphate via a random order mechanism. Inhibition studies provided evidence for the physiological role of G6PD as producer of NADPH in both fungi.
\end{abstract}

\section{Introduction}

In fungi, the pentose phosphate and mannitol pathways are the central routes for the production of NADPH (Hult \& Gatenbeck, 1978; McCullough et al., 1977). The enzymes that generate NADPH are glucose-6-phosphate dehydrogenase (G6PD) and 6-phosphogluconate dehydrogenase (6PGD) of the pentose phosphate pathway and mannitol dehydrogenase of the mannitol pathway. G6PD catalyses the first reaction of the pentose phosphate pathway. The main physiological role of the pentose phosphate pathway is to provide NADPH, the reducing agent in a large number of biosynthetic and detoxification reactions (Levy, 1979). Under physiological conditions the oxidation of G6P by G6PD will be the committing step (Beutler \& Kuhl, 1986).

G6PD is a ubiquitous enzyme, so widely distributed among prokaryotes and eukaryotes that it is considered a housekeeping enzyme (Levy, 1979). Detailed studies on this enzyme from filamentous fungi are scarce. Partial purification and characterization of the $A$. niger enzyme was reported by Jagannathan et al. (1956). Some characteristics of the enzymes from Neurospora crassa

\footnotetext{
*Author for correspondence. Fax +31 8370 83146; e-mail GENETICA@RCL.WAU.NL.
}

\footnotetext{
Abbreviations: G6P, glucose 6-phosphate; G6PD, glucose-6-phosphate dehydrogenase.
}

(Scott \& Tatum, 1970; Scott \& Mahony, 1976), Penicillium duponti and $P$. notatum (Malcolm \& Shepherd, 1972), Aspergillus parasiticus (Niehaus \& Dilts, 1984), Agaricus bisporus (Hammond, 1985) and Phycomyces blakesleanus (DeArriga et al., 1986) have been published.

The activity of the pentose phosphate pathway in $A$. nidulans is influenced by growth conditions in order to maintain a proper NADPH:NADP ${ }^{+}$ratio (Carter \& Bull, 1969; Bainbridge et al., 1971; McCullough et al., 1977; Singh et al., 1988). Regulation of the $\mathrm{NADPH}: \mathrm{NADP}^{+}$ratio is not only necessary to allow the use of certain carbon and nitrogen sources such as Dxylose and nitrate (Hankinson, 1974), but also affects the secondary metabolism. The NADPH:NADP ${ }^{+}$ratio has been shown to influence the type and relative amounts of polyols produced in both $A$. niger and $A$. nidulans (Dijkema et al., 1985, 1986) as well as the biosynthesis of polyketides in the fungi Alternaria alternata (Hult \& Gatenbeck, 1978) and A. parasiticus (Niehaus \& Dilts, 1984).

To study the regulation of the NADPH/NADP ${ }^{+}$ balance in aspergilli at the molecular level, we aimed to isolate and characterize both the enzymes and the genes governing decisive steps in the generation of NADPH. With the aid of the molecular genetic manipulation techniques developed for aspergilli (for a review see Goosen et al., 1992) it will be possible to relate gene structure and regulation of gene expression to the physiology of the organism. Here we report the isolation 
and characterization of glucose-6-phosphate dehydrogenase from $A$. niger and $A$. nidulans.

\section{Methods}

Strains and growth conditions. A. nidulans WG 096 yA2, pabaA1 and $A$. niger N402 cspA1 (strain collection, Department of Genetics, Agricultural University, Wageningen) were used as a source for enzyme purification. Conidiospores were harvested in $0.05 \%$ Tween 80 , $0.9 \% \mathrm{NaCl}$. After vigorous shaking the spore suspension was rinsed twice with $20 \mathrm{~mm}$-potassium phosphate $\mathrm{pH} 2.0$ for $A$. niger or $\mathrm{pH} 6.0$ for $A$. nidulans and used to inoculate $600 \mathrm{ml}$ of minimal medium (final concentration $2 \times 10^{7}$ spores $\mathrm{ml}^{-1}$ ) (Pontecorvo et al., 1953) with $2 \%$ (w/v) glucose. After shaking at 200 r.p.m. for $6 \mathrm{~h}$ at $37^{\circ} \mathrm{C}$ for $A$. nidulans or $30^{\circ} \mathrm{C}$ for $A$. niger the culture was added to 6.4 litres of the same medium in a 10 litre bottle. Cultures were heavily agitated by filter aeration for $25 \mathrm{~h}$ at $25^{\circ} \mathrm{C}$, a temperature favourable for the induction of glycolytic enzymes (Uitzetter, 1982). Mycelium was harvested by filtration through cheesecloth, washed with deionized water, blotted dry, frozen in liquid nitrogen and stored at $-80^{\circ} \mathrm{C}$.

Preparation of the affinity matrices. The reactive dyes were coupled according to a modified procedure of Dean \& Watson (1979). Sepharose CL-4B beads (Pharmacia) (200 g), extensively washed and suction filtered, were resuspended in $600 \mathrm{ml}$ water and mixed with $4 \mathrm{~g}$ Cibacron Blue 3G-A (Ciba-Geigy). Following solubilization of the dye, the $\mathrm{pH}$ was raised to $10-11$ by addition of $1 \mathrm{M}-\mathrm{Na}_{2} \mathrm{CO}_{3}$. The ionic strength was increased by addition of $120 \mathrm{ml} 3 \mathrm{M}-\mathrm{NaCl}$. Further treatment was as described by Uitzetter (1982). The reactive dye Procion Red P3 BN (ICI) was coupled to Sepharose CL-4B beads in a similar fashion.

Extraction and purification of the G6PD enzymes. All steps, except the FPLC runs, were carried out at $4{ }^{\circ} \mathrm{C}$. Frozen mycelium $(100 \mathrm{~g})$ was powdered in liquid nitrogen, resuspended in $500-600 \mathrm{ml}$ extraction buffer A (20 mM-potassium phosphate buffer $\mathrm{pH} \mathrm{6.8,1}$ mM-EDTA, $2 \mathrm{mM}-\mathrm{MgCl}_{2}$ and $\left.50 \mu \mathrm{M}-\mathrm{PMSF}\right)$ and stirred for $90 \mathrm{~min}$. The cleared extract $(20 \mathrm{~min}, 12000 \mathrm{~g})$ was ammonium sulphate fractionated (15-65\% saturation) and the precipitate was dissolved in $50 \mathrm{ml}$ buffer A. After dialysis against buffer $\mathrm{A}$ the mixture was applied to a buffer A-equilibrated Cibacron Blue column (bed volume $100 \mathrm{ml}$ ), washed with 3 vols of buffer $A$ and eluted with a linear gradient of $0-2 \mathrm{M}-\mathrm{NaCl}$ in buffer $\mathrm{A}$. Active fractions, eluting at $0.8-1 \mathrm{M}-\mathrm{NaCl}$, were pooled and dialysed overnight against buffer $\mathrm{A}$. This dialysate was loaded on a buffer A-equilibrated FPLC-Mono Q HR 5/5 (Pharmacia) anion exchange column (bed volume $4 \mathrm{ml}$ ) at room temperature. The column was washed with buffer $\mathbf{A}$ and eluted with a non-linear gradient of $0-2 \mathrm{M}-\mathrm{NaCl}$ in buffer $\mathrm{A}$; this gradient had a fairly flat slope from $0-1 \mathrm{M}$ followed by a steep slope from 1-2 $\mathrm{M}$. Active fractions eluting at $0 \cdot 8-1.0 \mathrm{M}-\mathrm{NaCl}$ were pooled, dialysed against buffer $\mathrm{A}$, reloaded on a buffer A-equilibrated FPLC-Mono Q HR 5/5 column and eluted with a non-linear 0-1.0 $\mathrm{M}-\mathrm{NaCl}$ gradient (flat slope from $0-0.8 \mathrm{M}-\mathrm{NaCl}$ and a steep slope thereafter) in buffer A. Active fractions were again pooled, dialysed against buffer $\mathrm{A}$ and rechromatographed on a $5 \mathrm{ml}$ Cibacron Blue column with a linear $0-2 \mathrm{M}-\mathrm{NaCl}$ gradient in buffer A. After pooling and dilution of the active fractions this last step was repeated. The G6PD-containing fractions were stored at $4{ }^{\circ} \mathrm{C}$ and for some purposes dialysed against buffer $\mathbf{A}$ and lyophilized in a Speedvac.

Enzyme assays. G6PD activity was measured at $30^{\circ} \mathrm{C}$ in $50 \mathrm{~mm}-$ triethanolamine (pH 7.5), 5 mM-EDTA according to Löhr \& Waller (1974). Under standard conditions the reaction mixture contained $790 \mu \mathrm{M}-\mathrm{NADP}^{+}$and $720 \mu \mathrm{M}-\mathrm{G} 6 \mathrm{P}$ (Boehringer Mannheim). One enzyme unit is defined as the amount of enzyme required to reduce $1 \mu \mathrm{mol}$ $\mathrm{NADP}^{+}$under the conditions specified. Effects of various compounds were examined by either incorporating them into the reaction mixture or preincubating the enzyme before adding substrates. Kinetic parameters were determined by least square regression; plotting of lines, replotting of intercepts and slopes were performed using Harvard Graphics.

Protein concentrations were determined by the Lowry method or using the Bio-Rad assay.

Polyacrylamide gel electrophoresis. Electrophoresis of native proteins was carried out in $10 \%(\mathrm{w} / \mathrm{v})$ polyacrylamide gels at $\mathrm{pH} 8.9$ as described by Davis (1964). Proteins were stained with Coomassie Brilliant Blue R-250. G6PD activity in native gels was detected as described by Shaw \& Prasat (1970). SDS-PAGE was performed by the method of Laemmli (1970). Isoelectric focusing was performed in $5 \%$ polyacrylamide slab gels containing ampholytes spanning a $5-8 \mathrm{pH}$ range, using the FBE 3000 apparatus (Pharmacia) according to a protocol supplied by the manufacturer. A standard mixture (Serva) of amyloglucosidase (pI 3.5), ferritin (4.4), bovine albumin (4.7), $\beta$ lactoglobulin (5.34), conalbumin (5.9), horse myoglobin (7.3), whale myoglobin (8.3), ribonuclease (9.45) and cytochrome $c(10.65)$ was used to calibrate the gradient.

Production of antisera. Antibodies were raised in male New Zealand White rabbits by injecting purified $A$. nidulans or $A$. niger G6PD in Freund's complete adjuvant on day 1 and day 30 . Antibody titres were checked $9 \mathrm{~d}$ after the second injection in an Ouchterlony agar diffusion test (Ouchterlony \& Nilson, 1978). Two days later blood was collected, allowed to clot for $1-2 \mathrm{~h}$ at $25^{\circ} \mathrm{C}$, left overnight at $4{ }^{\circ} \mathrm{C}$ and spun to collect the antiserum. The antiserum was stored at $-20^{\circ} \mathrm{C}$. Antibodies against a commercial preparation of Saccharomyces cerevisiae G6PD (Boehringer Mannheim) were kindly provided by H. C. M. Kester (Dept. of Genetics, Wageningen).

Western blotting and G6PD specific enzyme immunoassay. Proteins were transferred from SDS-polyacrylamide gels to nitrocellulose (Schleicher and Schuell BA-85) by electroblotting in $25 \mathrm{~mm}-\mathrm{Tris}$, $192 \mathrm{~mm}$-glycine $(\mathrm{pH} 8.3)$ and $20 \%(\mathrm{v} / \mathrm{v})$ methanol for $3 \mathrm{~h}$ at $60 \mathrm{~V}$ $(200 \mathrm{~mA})$. Blots were blocked in $3 \%(\mathrm{w} / \mathrm{v})$ gelatin in $20 \mathrm{mM}-\mathrm{Tris} / \mathrm{HCl}$ (pH 7.5) and $0.5 \mathrm{M}-\mathrm{NaCl}$. After extensive washing, the blots were incubated with G6PD antibody diluted in blocking buffer $(1: 250)$ at room temperature for at least $2 \mathrm{~h}$ with gentle agitation. Again the blots were washed and incubated with diluted $(1: 3000)$ goat anti-rabbit gamma-globin-alkaline phosphatase conjugate and finally stained with the Immune Blot assay kit according to the manufacturer's instructions (Bio-Rad). For the G6PD specific enzyme immunoassay, the G6PD antibody-incubated blots were washed in buffer $A$ and subsequently incubated for at least $4 \mathrm{~h}$ at room temperature with 2-3 $\mathrm{U}$ of either $A$. nidulans or S. cerevisiae G6PD enzyme in buffer A. After removal of unbound G6PD the blots were stained for G6PD activity according to Shaw \& Prasat (1970).

Determination of molecular mass by gel filtration. Gel filtration was carried out at $4{ }^{\circ} \mathrm{C}$ either on a $83 \times 2 \mathrm{~cm}$ Sephacryl S-300 or a Sephacryl S-200 (Pharmacia) column equilibrated with buffer A. The column was calibrated using ferritin $(450 \mathrm{kDa})$, catalase $(240)$, aldolase $(160)$ and bovine serum albumin $(68)$.

\section{Results}

\section{Enzyme purification}

G6PD from $A$. niger and $A$. nidulans were purified by exactly the same procedure. Starting with $100 \mathrm{~g}$ of frozen mycelium, recoveries of $15-30 \%$ were usually obtained with an overall 500-1000-fold purification. Represen- 
Table 1. Purification of $A$. niger and A. nidulans glucose-6-phosphate dehydrogenases

\begin{tabular}{|c|c|c|c|c|c|c|}
\hline $\begin{array}{l}\text { Purification } \\
\text { step }\end{array}$ & $\begin{array}{l}\text { Volume } \\
\text { (ml) }\end{array}$ & $\begin{array}{l}\text { Total } \\
\text { activity* } \\
\text { (U) }\end{array}$ & $\begin{array}{l}\text { Total } \\
\text { protein } \\
(\mathrm{mg})\end{array}$ & $\begin{array}{c}\text { Specific } \\
\text { activity } \\
\left(\mathrm{U} \mathrm{mg}^{-1}\right)\end{array}$ & $\begin{array}{l}\text { Yield } \\
(\%)\end{array}$ & $\begin{array}{l}\text { Purification } \\
\text { (-fold) }\end{array}$ \\
\hline \multicolumn{7}{|l|}{ (a) A. niger } \\
\hline Homogenate & 500 & 458 & 803 & 0.57 & 100 & 1 \\
\hline $\begin{array}{l}\left(\mathrm{NH}_{4}\right)_{2} \mathrm{SO}_{4} \\
\text { precipitation }\end{array}$ & 65 & 803 & 450 & $1 \cdot 8$ & 175 & $3 \cdot 2$ \\
\hline Cibacron Blue 1 & 43 & 586 & $22 \cdot 5$ & 26 & 127 & 46 \\
\hline Mono Q 1 & 5 & 381 & $3 \cdot 2$ & 117 & 82 & 206 \\
\hline Mono $\mathrm{O} 2$ & 3 & 278 & 1.05 & 265 & 61 & 467 \\
\hline Cibacron Blue 2 & 4 & 195 & 0.35 & 556 & 42 & 976 \\
\hline \multicolumn{7}{|l|}{ (b) A. nidulans } \\
\hline Homogenate & 750 & 1507 & 1800 & 0.84 & 100 & 1 \\
\hline $\begin{array}{l}\left(\mathrm{NH}_{4}\right)_{2} \mathrm{SO}_{4} \\
\text { precipitation }\end{array}$ & 65 & 1541 & 906 & $1 \cdot 7$ & 102 & $2 \cdot 0$ \\
\hline Cibacron Blue 1 & 40 & 1028 & $46 \cdot 4$ & $22 \cdot 2$ & 68 & 26 \\
\hline Mono Q 1 & 3 & 767 & $3 \cdot 0$ & 256 & 51 & 304 \\
\hline Mono 02 & 3 & 743 & 1.5 & 495 & 49 & 589 \\
\hline Cibacron Blue 2 & $8 \cdot 25$ & 265 & $0 \cdot 41$ & 646 & 18 & 769 \\
\hline
\end{tabular}

*1 unit of G6PD activity is the amount of enzyme required to produce $1 \mu \mathrm{mol} \mathrm{NADPH} \mathrm{min}^{-1}$ $(\mathrm{mg} \text { protein })^{-1}$.

tative examples of the purification of the $A$. niger and $A$. nidulans enzymes are presented in Table 1.

In the first step (ammonium sulphate fractionation) a recovery of more than $100 \%$ was consistently observed, presumably due to the removal of interfering material from the homogenate, resulting in some activation of the enzyme. In the affinity chromatography step some irreversible binding of G6PD to the Cibacron Blue matrix was observed. After the resin had been used once no more activity was lost. This step allowed the removal of large amounts of protein with excellent recovery of activity. Elution of the Cibacron Blue column with $100 \mu \mathrm{M}-\mathrm{NADP}^{+}$did not result in the release of bound enzyme. However pre-incubation of a purified enzyme preparation with $\mathrm{NADP}^{+}$before application resulted in reduced affinity for this matrix. In this respect, results are in accordance with those for yeast (Reuter et al., 1986), but contrast with those for sea urchin (Matsuoka, 1988). Procion Red P3BN (Reuter et al., 1986) was tested as an alternative matrix for enzyme purification; the affinity was much lower than for Cibacron Blue and consequently recoveries were poor. Also no elution of enzyme activity from this resin was observed with $100 \mu \mathrm{M}-$ NADP $^{+}$.

\section{Purity and homogeneity of the enzyme preparations}

As judged from native acrylamide gels, both $A$. niger and $A$. nidulans G6PD enzyme preparations showed two bands when stained for protein. The same bands were also observed when the gels were stained for G6PD activity (data not shown). For $A$. nidulans one band was

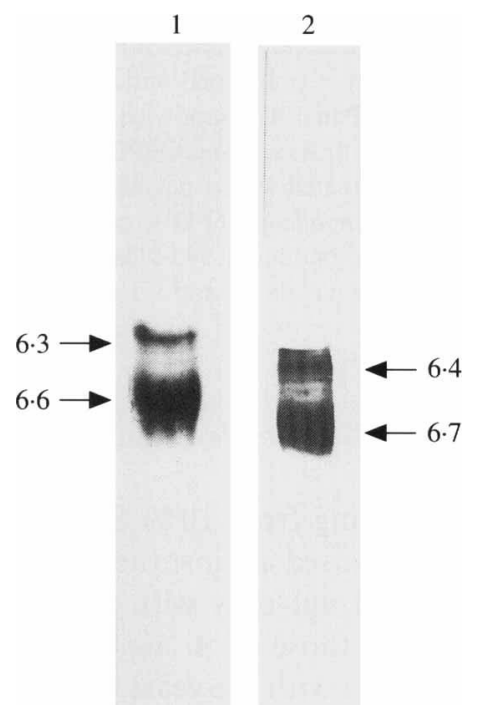

Fig. 1. Isoelectric focusing of purified glucose-6-phosphate dehydrogenase from $A$. nidulans and $A$. niger. IEF was performed in $5 \%$ (w/v) polyacrylamide gel slabs containing ampholytes for the $\mathrm{pH}$ range 5-8. Protein bands were visualized by staining for G6PD activity. pI values for the different enzyme forms as derived from a calibration standard are indicated. Lane 1, 0.8 U A. nidulans enzyme; lane 2, $0.3 \mathrm{U} A$. niger enzyme.

usually more prominent. Moreover the relative intensity of the two bands varied from one preparation to another. For $A$. niger these differences were less pronounced. Both purified G6PD preparations also separated into double bands with different intensities on $10 \%$ SDS-polyacrylamide gels.

In IEF gels (Fig. 1) double bands with similar intensities were observed. The deduced isoelectric points 

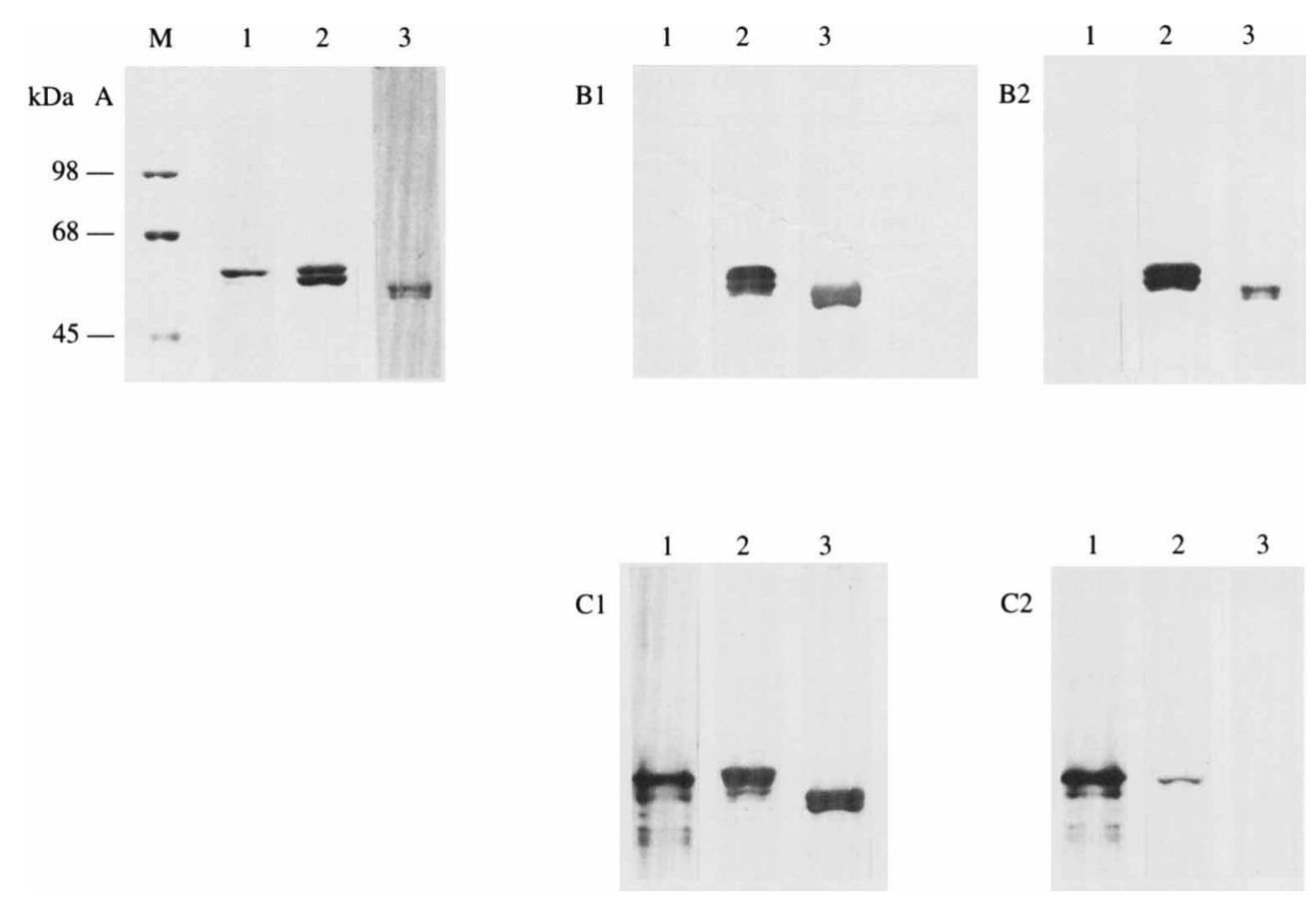

\begin{abstract}
Fig. 2. Immunological detection of glucose-6-phosphate dehydrogenase protein bands from $A$. nidulans and $A$. niger. Denatured proteins were separated on SDS-polyacrylamide gels and either stained for protein (panel A) or used for Western blotting and immunochemical detection (panels B and C) as described in Methods. Panel A, Coomassie Brilliant Blue staining; panel B1, Western blot incubated with a polyclonal antiserum directed against $A$. nidulans G6PD and detection with alkaline phosphatase-conjugated second antibody; Panel B2, 'sandwich' blot incubated with a polyclonal antiserum raised against $A$. nidulans G6PD and detection by activity staining with $A$. nidulans G6PD; panel $\mathrm{C} 1$, as $\mathrm{B} 1$ but incubated with a polyclonal antiserum raised against yeast G6PD; panel $\mathrm{C} 2$, as $\mathrm{B} 2$ but incubated with a polyclonal yeast G6PD antiserum and detection by activity staining with yeast G6PD. Lanes 1 , yeast G6PD; lanes 2, A. nidulans G6PD; lanes 3, A. niger G6PD; lane M, molecular mass markers: phosphorylase b (98 kDa), bovine serum albumin $(68 \mathrm{kDa})$, ovalbumin $(45 \mathrm{kDa})$, carbonic anhydrase $(29 \mathrm{kDa})$. The amounts of protein applied were, respectively, $2-4 \mu \mathrm{g}$ in panel $\mathrm{A}, 1-2 \mu \mathrm{g}$ in panels $\mathrm{B} 1$ and $\mathrm{C} 1$ and $0 \cdot 2-0 \cdot 4 \mu \mathrm{g}$ in panels $\mathrm{B} 2$ and $\mathrm{C} 2$.
\end{abstract}

were 6.3 and 6.6 for $A$. nidulans and 6.4 and 6.7 for $A$. niger.

On Western blotting from $10 \%$ SDS-polyacrylamide gels the antiserum, raised against the $A$. nidulans enzyme preparation, reacted not only with the two $A$. nidulans bands but also with those of $A$. niger (Fig. 2, B1). Only a weak cross-reaction with the yeast G6PD was observed (Fig. 2, B1). Similarly, the Aspergillus doublets reacted with antibodies raised against the yeast G6PD, indicating that both bands are related to the yeast G6PD. The reaction of this yeast antiserum with the yeast G6PD enzyme preparation was much stronger and showed multiple degradation products (Fig. 2, $\mathrm{Cl}$ ) besides a major band.

\section{G6PD specific detection of multiple monomers}

To demonstrate that both bands visible in Coomassiestained SDS-polyacrylamide gels and Western blots were implicated in G6PD activity, 'sandwich' blotting was devised. Western blots were incubated with an excess of $A$. nidulans antiserum and, after removal of unbound antibody, they were incubated with the homologous purified G6PD enzyme preparation. Antibody-bound G6PD was subsequently detected by activity staining.

As shown in Fig. 2, B2, both bands in the $A$. nidulans and $A$. niger enzyme preparations could be detected with the $A$. nidulans antiserum and enzyme. The yeast enzyme could not be detected with the $A$. nidulans antiserum/ enzyme combination. The doublets in the $A$. nidulans preparation gave a stronger signal than the two bands in the $A$. niger preparation. Conversely with the $A$. niger G6PD antiserum and enzyme, the two bands in the $A$. niger preparation stained more strongly than the $A$. nidulans doublets (not shown). In a similar experiment with the yeast antiserum and enzyme preparation, the yeast bands stained heavily. Additionally, only one weak band was observed in the $A$. nidulans preparation and no signal was found for $A$. niger (Fig. 2, C2).

The specificity and sensitivity of the G6PD 'sandwich' Western blot were so high, that for $A$. niger as well as for $A$. nidulans the two monomeric forms could be detected in 15-30 $\mu \mathrm{g}$ protein of a crude extract. Non-specific bands, sometimes observed in normal Western blots, 
were completely absent in the 'sandwich' blots. These results strongly indicate, that our final G6PD preparations were pure, although not homogeneous.

\section{Molecular masses}

From SDS-polyacrylamide gels (Fig. 2A), the molecular masses of the monomers involved in G6PD activity were estimated to be 55 and $53 \mathrm{kDa}$ for $A$. niger and 60 and $57 \mathrm{kDa}$ for $A$. nidulans. The molecular mass of the $S$. cerevisiae G6PD monomer was estimated to be $59 \mathrm{kDa}$.

The elution profiles of Sephacryl S300 as well as S200 gel filtration columns indicated a molecular mass for the native enzyme of $160 \mathrm{kDa}$ for $A$. niger and $180 \mathrm{kDa}$ for $A$. nidulans. G6PD activity could not be detected in other column fractions, which suggests the absence of active monomers and dimers.

\section{Kinetics and substrate specificity}

For both Aspergillus enzymes a broad pH vs. initial velocity curve was obtained, with an optimum ranging from $\mathrm{pH} 7.0$ to 9.0 (not shown). Under standard assay conditions the relationship between the amount of enzyme added and the initial reaction velocity was linear. Within this linear range the reaction parameters were analysed.

The $A$. nidulans and $A$. niger enzymes exhibited absolute specificity towards the substrates G6P and $\mathrm{NADP}^{+}$. No activity was observed with $\mathrm{NAD}^{+}$(up to $1 \mathrm{~mm}$ ), glucose, glucose 1-phosphate, 2-deoxyglucose 6phosphate, fructose, fructose 6-phosphate, fructose 1,6diphosphate, mannose or galactose 6-phosphate (up to $600 \mu \mathrm{M})$.

With the two substrates normal hyperbolic saturation curves were obtained and the double reciprocal plots were linear. The $1 / V$ vs $1 /[\mathrm{G} 6 \mathrm{P}]$ plots intersected at a common point above the abscissa. The kinetic parameters of $A$. nidulans and $A$. niger were deduced from Eadie-Hofstee plots of the data of the initial velocity experiments. Fig. 3 shows an example for the $A$. nidulans enzyme. The kinetic parameters are summarized in Table 2.

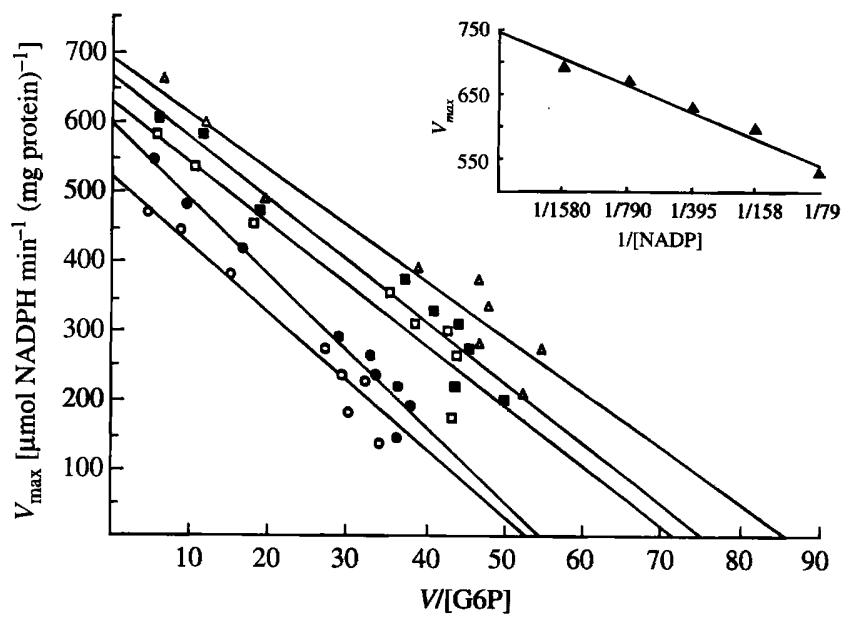

Fig. 3. Kinetics of $A$. nidulans glucose-6-phosphate dehydrogenase. Eadie-Hofstee plot: initial velocity vs the ratio of initial velocity and glucose-6-phosphate concentrations, determined at several fixed $\mathrm{NADP}^{+}$concentrations. From the slopes of these plots the $K_{\mathrm{m}}$ for G6P was calculated and from replots of the intercepts with the ordinate vs $1 /\left[\mathrm{NADP}^{+}\right]$the maximal velocity was deduced (see insert). Assays were done at $30^{\circ} \mathrm{C}$ with $0.05 \mathrm{U} A$. nidulans G6PD. Velocities are expressed as $\mu$ mol NADPH $\min ^{-1}$ (mg protein) ${ }^{-1}$. $\bigcirc, 79 \mu \mathrm{M}-\mathrm{NADP}^{+} ;$, $158 \mu \mathrm{M}$ $\mathrm{NADP}^{+} ; \square, 395 \mu \mathrm{M}-\mathrm{NADP}^{+} ; \boldsymbol{\square}, 790 \mu \mathrm{M}-\mathrm{NADP}^{+}$and $\triangle, 1580 \mu \mathrm{M}-$ $\mathrm{NADP}^{+}$.

The effect of NADPH on the initial reaction velocity was studied in more detail at several fixed concentrations of one substrate and a variable concentration of the other. For both enzymes an almost ideal competitive inhibition was observed with respect to $\mathrm{NADP}^{+}$. For G6P this was less clear, although competition was apparent. The $K_{\mathrm{i}}(\mathrm{NADPH})$ value for the $A$. nidulans enzyme preparation was deduced and shown to be in the same order as the $K_{\mathrm{m}}$ for $\mathrm{NADP}^{+}$. Because of the instability of the second reaction product, 6-phosphoglucono- $\delta$-lactone, it was not tested. Under normal physiological conditions this compound might be expected to be removed immediately (Beutler \& Kuhl, 1986). The effect of specific compounds, known to influence G6PD from other sources, e.g. AMP, ADP, ATP, palmitoyl-CoA, pyridoxal-5-phosphate and acetylsalicylic acid on the initial reaction velocity was investigated under standard conditions and in some

Table 2. Kinetic parameters for $A$. nidulans and A. niger G6PD enzymes

\begin{tabular}{lcccc}
\hline \hline & $K_{\mathrm{m}}(\mathrm{G} 6 \mathrm{P})$ & $K_{\mathrm{m}}(\mathrm{NADP})$ \\
$(\mu \mathrm{M})$ & $\begin{array}{c}K_{\mathrm{i}}(\mathrm{NADPH}) \\
(\mu \mathrm{M})\end{array}$ & $\begin{array}{c}V_{\max } \\
{[\mu \mathrm{mol} \text { NADPH }} \\
\min ^{-1} \\
\left.(\mathrm{mg} \text { protein })^{-1}\right]\end{array}$ \\
\hline A. niger & $153 \pm 10$ & $26 \pm 8$ & $\mathrm{ND}$ & 790 \\
A. nidulans & $92 \pm 10$ & $30 \pm 8$ & $20 \pm 5$ & 745 \\
\hline \hline
\end{tabular}


cases at a range of substrate concentrations. No significant effects were observed. High ATP concentrations ( $>2-4 \mathrm{~mm}$ ) inhibited the enzyme slightly, but inhibition was not related to the NADPH:NADP ${ }^{+}$ratio as in Candida maltosa H (Röber et al., 1984).

\section{Discussion}

In this paper we report on a fast and efficient purification of glucose-6-phosphate dehydrogenase from two $A s$ pergillus species. This procedure can be completed in $2 \mathrm{~d}$ and results in pure preparations with high specific activities. This is mainly due to the use of the affinity dye Cibacron Blue which, because of its high and specific binding capacity for G6PD, is effective in removing large amounts of contaminating proteins.

Final preparations showed double bands in both native and isoelectric focusing gels, each of which represented an enzymic form of G6PD as judged by activity staining in gels. The presence of multiple G6PD enzymes is not unprecedented since multiple bands have been observed in bacteria, plants, animals and insects. In general it used to be assumed that different multimers of one basic subunit were responsible for this phenomenon (Levy, 1979). The observation of double bands in the SDS-polyacrylamide gels suggests that there could be two separate monomeric forms of G6PD in aspergilli. Although not excluding the possibility of contamination, detection of two bands in both preparations on Western blots, irrespective of the antiserum used, supports this suggestion.

The cross reaction of the $A$. nidulans antiserum is much stronger with the $A$. niger G6PD than with the $S$. cerevisiae G6PD. This strongly suggests that the two Aspergillus G6PDs are more closely related to each other than to S. cerevisiae G6PD. Definite proof for the G6PD specificity of the monomers was obtained using the 'sandwich' blot. In this procedure the divalent nature of immunoglobins is exploited. After binding of the antibody to the denatured protein on the Western blot, some of the antigen binding sites will still be available for the binding of native G6PD, provided that the protein on the blot is at least related to G6PD. Using a G6PD activity stain only G6PD specific antibodies are detected. Application of this technique is by no means limited to G6PD but can be used to detect any enzyme immunologically as long as a specific activity stain is available.

Combining these results with the data from nondenaturing and isoelectric focusing gels, we speculate that in aspergilli two G6PDs with multimeric structures consisting of two different monomers are present. Our gel filtration data are in agreement with the molecular mass of $190 \mathrm{kDa}$, previously obtained for partially purified $A$. nidulans G6PD (Malathi \& Shanmugas- undaram, 1987) and suggest a trimeric structure for the active forms from both fungi. However dimers and tetramers tend to be the rule for active G6PDs (Bonsignore \& De Flora, 1972; Levy, 1979). Retardation by interaction with Sephadex G-200, resulting in an underestimation of the molecular mass, has been reported for G6PD of $A$. parasiticus and $S$. cerevisiae by Niehaus \& Dilts (1984). To resolve the question whether the native G6PD is indeed a tetramer, SDS-PAGE of chemically cross-linked subunits might be an alternative.

Because of the small differences in molecular mass and the limited resolution of gel filtration, we cannot tell whether the G6PDs are homomeric or heteromeric structures. Assuming a tetrameric structure for both G6PDs, the observation of only two and not five bands on non-denaturing gels points towards a highly specific aggregation. The variability of relative intensities of the bands observed between different isolates can be used as an argument for proteolytic degradation, post-translational modification or even different subunits derived from two genes.

Aspergilli are known to produce substantial amounts of various proteases (van den Hondel et al., 1992) and so heterogeneity caused by limited proteolysis cannot be excluded, even though PMSF was included in all buffers at all stages. Since PMSF and EDTA inhibit only specific classes of proteases, the chance of proteolytic degradation during isolation could be reduced by employing cocktails of protease inhibitors. In this respect it is interesting to note that the multiple subunit composition reported for the arom multi-enzyme complex from $N$. crassa was shown to be the result of proteolytic degradation during isolation. If protease activity is stringently controlled during isolation the arom multienzyme complex can be shown to be composed of two, probably identical, subunits (Lumsden \& Coggins, 1977).

Post translational modification of G6PD has been reported for several cell types in humans in relation to differentiation, aging and disease (Levy, 1979). The isolation of a 'G6PD modifying factor' from human leukaemic granulocytes has been reported (Kahn et al., 1976). The exact nature of these modifications however has not been elucidated, but they did not alter the molecular mass of the enzyme.

In Acetobacter hansenii two different G6PD enzymes are encoded by separate genes. These enzymes however, have a distinct cofactor specificity: one is $\mathrm{NAD}^{+}$specific and the other is $\mathrm{NADP}^{+}$specific (Levy \& Cook, 1991). This cannot be related directly to the double bands observed in both Aspergillus enzyme preparations, since they were shown to exhibit absolute specificity towards $\mathrm{NADP}^{+}$.

Interestingly the $\mathrm{NADP}^{+}$-specific G6PD from the fungus $N$. crassa also shows multiple bands on native 
and isoelectric focusing gels at all stages of purification. Although only one band with a molecular mass of $57 \mathrm{kDa}$ is observed on SDS-polyacrylamide gels, mutations in four unlinked genes lead to G6PD enzymes with altered electrophoretic and catalytic properties (Scott \& Tatum, 1970; Scott \& Mahony, 1976; Nishikawa \& Kuwana, 1985). Though definite proof has never been obtained, these four genes are thought to represent structural genes for G6PD (Scott \& Mahony, 1976).

In Aspergillus oryzae two G6PD species are present in glucose-grown mycelium and a third one is specifically induced during growth on ribose. These G6PD enzymes have distinct catalytic properties and molecular masses of 92, 117.5 and $141 \mathrm{kDa}$ (Muiño Blanco et al., 1983; Cébrian-Pérez et al., 1989). Since no SDS-polyacrylamide gel data were presented by the authors it is difficult to assess whether the observed enzyme forms are due to different aggregation states or to different types of subunits.

The Michaelis constants for $A$. nidulans G6PD differed from the ones determined $\left[K_{\mathrm{m}}(\mathrm{G} 6 \mathrm{PD}) 20 \mu \mathrm{M}\right.$ and $\left.K_{\mathrm{m}}\left(\mathrm{NADP}^{+}\right) 77 \mu \mathrm{M}\right]$ by Malathi \& Shanmugasundaram (1987) for a partially pure preparation. The value for the $K_{\mathrm{m}}(\mathrm{G} 6 \mathrm{PD})(170 \mu \mathrm{M})$ for a partially purified $A$. niger G6PD determined by Jagannathan et al. (1956) agrees with our data. The $K_{\mathrm{m}}$ and $V_{\max }$ for both Aspergillus G6PDs were in the same range as those reported for $P$. duponti, $P$. notatum, $A$. bisporus, $S$. cerevisiae, Candida maltosa $\mathrm{H}$ and both G6PDs from $A$. oryzae present in mycelium grown on glucose but differed markedly from those reported by Niehaus \& Dilts (1984) for the G6PD isolated from $A$. parasiticus.

The kinetic data for both enzyme preparations are similar to those obtained with enzyme preparations from other sources (Bonsignore \& De Flora, 1972; Levy, 1979), e.g. absolute specificity for both substrate (G6P) and cofactor $\left(\mathrm{NADP}^{+}\right)$, high affinity for both substrates and strong competitive inhibition by NADPH. The double reciprocal plots of the initial velocity data have an intersecting pattern of lines, which rules out the possibility of a ping-pong mechanism. Since NADPH is a competitive inhibitor with respect to both $\mathrm{NADP}^{+}$and G6P, a rapid equilibrium random mechanism fits our data best. A similar mechanism has been proposed for G6PD from $P$. duponti, $P$. notatum (Malcolm \& Shepherd, 1972), and Saccharomyces carlsbergensis (Holten et al., 1976). For G6PD from human, pig and rat liver an ordered mechanism has been deduced from inhibition studies (Levy, 1979).

The high ATP concentration needed for inhibition and the absence of any correlation with the NADPH: NADP ${ }^{+}$ ratio make it questionable whether this inhibition has any physiological significance. Such a correlation was clearly demonstrated for $C$. maltos $\mathrm{H}$, where the pentose phosphate pathway serves as an alternative for glycolysis to generate glyceraldehyde 3-phosphate (Röber et al., 1984). This supports the view that in aspergilli the pentose phosphate pathway is mainly involved in providing NADPH for anabolic purposes. In general it can be stated that in both Aspergillus species the G6PD activity is regulated by the NADPH: $\mathrm{NADP}^{+}$ratio.

Since reactive lysine residues, which can be modified by pyridoxal-5-phosphate (Vincenzini et al., 1986; Camardella et al., 1988) and acetylsalicylic acid (Han et al., 1980; Jeffery et al., 1985) occupy similar positions in G6PD enzymes of widely different origin, the absence of any effect of these compounds on the Aspergillus enzymes is surprising. The result appears particularly peculiar since sequence analysis of the G6PD encoding genes recently isolated from $A$. niger and $A$. nidulans showed that such a lysine is present in both enzymes in a highly conserved sequence context (P. J. H. van den Broek and others, unpublished results).

\section{References}

Bainbridge, B. W., Bull, A. T., Pirt, S. J., Rowley, B. I. \& Trinci, A. P. (1971). Biochemical and structural changes in non-growing and autolysing cultures of Aspergillus nidulans. Transactions of the British Mycological Society 56, 371-375.

Beutler, E. \& KuHL, W. (1986). Characteristics and significance of the reverse glucose-6-phosphate dehydrogenase reaction. Journal of Laboratory and Clinical Medicine 107, 502-507.

Bonsignore, A. \& DE FlorA, A. (1972). Regulatory properties of glucose-6-phosphate dehydrogenase. In Current Topics in Cellular Regulation, vol. 6, pp. 21-62. Edited by B. L. Hoecker \& E. R. Stadtman. New York: Academic Press.

Camardella, L., Caruso, C., Rutigliano, B., Romano, M., Di PrisCo, G. \& Descalzi-CANCEDdA (1988). Human erythrocyte glucose-6-phosphate dehydrogenase. Identification of a reactive lysyl residue, labelled with 5'-pyridoxal phosphate. European Journal of Biochemistry 171, 485-489.

Carter, B. L. A. \& Bull, A. T. (1969). Studies of fungal growth and intermediary carbon metabolism and non-steady-state conditions. Biotechnology and Bioengineering 11, 785-804.

Cébrian-Pérez, J. A., Muiño-Blanco, T., Pérez-Martos, A. \& LóPEZ-PÉrez, M. J. (1989). Characterisation of three enzymatic forms of glucose-6-phosphate dehydrogenase from Aspergillus oryzae. Revista Espanola de Fisiologica 45, 271-276.

Davis, B. J. (1964). Disc electrophoresis II. Method and applications to human serum proteins. Annals of the New York Academy of Sciences 121, $404-427$.

Dean, P. D. G. \& Watson, D. M. (1979). Protein purification using immobilized triazine dyes. Journal of Chromatography 165, 301-319.

DeArriga, D., Montero, S., Busto, F. \& Soler, J. (1986). Partial purification and some kinetic properties of glucose-6-phosphate dehydrogenase from Phycomyces blakesleanus. Biochimie 68, 293-302.

Dijkema, C., Kester, H. C. M. \& Visser, J. (1985). ${ }^{13}$ C-NMR studies on carbon metabolism in the hyphal fungus Aspergillus nidulans. Proceedings of the National Academy of Sciences of the United States of America 82, 14-18.

Dijkema, C., Pels Rijcken, R., Kester, H. C. M. \& Visser, J. (1986) ${ }^{13} \mathrm{C}-\mathrm{NMR}$ studies on the influence of $\mathrm{pH}$ and nitrogen source on the polyol pool formation in Aspergillus nidulans. FEMS Microbiology Letters 33, 125-131.

Goosen, T., Bos, C. J. \& VAN den Broek, H. W. J. (1992). Transformation and gene manipulation in filamentous fungi; an overview. In Handbook of Applied Mycology, vol. 4, Fungal Biotechnology, pp. 
151-195. Edited by D. K. Arora, R. P. Elander \& K. G. Mukerji. New York: Marcel Dekker.

HAMmOND, J. B. W. (1985). Glucose-6-phosphate dehydrogenase from Agaricus bisporus: purification and properties. Journal of General Microbiology 131, 321-328.

HaN, P. F., HaN, G. Y., McBay, H. C. \& Johnson, J. JR (1980). Inactivation of yeast glucose-6-phosphate dehydrogenase by aspirin. Experientia 36, 1149-1150.

HaNKINSON, O. (1974). Mutants of the pentose phosphate pathway in Aspergillus nidulans. Journal of Bacteriology 117, 1121-1130.

Holten, D., Proscal, D. \& Chang, H.-L. (1976). Regulation of the pentose phosphate pathway by the $\mathrm{NADP}^{+} / \mathrm{NADPH}$ ratio. Biochemical and Biophysical Research Communications 68, 436-441.

van Den Hondel, C. A. M. M. J., Punt, P. J. \& VAN Gorcom, R. F. M. (1992). Production of extracellular proteins by the filamentous fungus Aspergillus. Antonie van Leeuwenhoek 61, 153-160.

Hult, K. A. \& GATENBECK, S. (1978). Production of NADPH in the mannitol cycle and its relation to polyketide formation in Alternaria alternata. European Journal of Biochemistry 88, 607-612.

Jagannathan, V., Rangachari, P. N. \& Damodaran, M. (1956). Carbohydrate metabolism in citric acid fermentation. 5. Purification and properties of Zwischenferment from $A$. niger. Biochemical Journal 64, 477-481.

JeFFerY, J., HoBBS, L. \& JORNVALl, H. (1985). Glucose-6-phosphate dehydrogenase from $S$. cerevisiae: characterization of a reactive lysine residue labelled with acetylsalicylic acid. Biochemistry 24, 666-671.

KahN, A., Boivin, P., Rubinson, H., Cottreau, D., Marie, J. \& DREYFUS, J.-C. (1976). Modification of purified glucose-6-phosphate dehydrogenase and other enzymes by a factor of low molecular weight in some leukemic cells. Proceedings of the National Academy of Sciences of the United States of America 73, 77-81.

LAEMMLI, U. K. (1970). Cleavage of structural proteins during the assembly of the head of bacteriophage T4. Nature, London 227, $680-685$.

LEVY, H. R. (1979). Glucose-6-phosphate dehydrogenases. Advances in Enzymology 48, 97-192.

LEVY, H. R. \& CoOK, C. (1991). Purification and properties of NADPlinked glucose-6-phosphate dehydrogenase from Acetobacter hansenii (Acetobacter xylinium). Archives of Biochemistry and Biophysics 291, 161-167.

LöHR, G. W. \& Waller, H. D. (1974). Glucose-6-phosphate dehydrogenase. In Methoden der enzymatischen Analyse, vol. 1, pp. 673-681. Edited by H. U. Bergmeyer. Weinheim: Verlag Chemie GMBH.

LumSDEN, J. \& CoGgINs, J. R. (1977). The subunit structure of the arom multienzyme complex of Neurspora crassa. Biochemical Journal 161, 599-607.

McCullough, W., Payton, M. A. \& Roberts, C. F. (1977). Carbon metabolism in Aspergillus nidulans. In Genetics and Physiology of
Aspergillus, pp. 97-129. Edited by J. E. Smith \& J. A. Pateman. New York: Academic Press.

Malathi, S. \& Shanmugasundaram, E. R. B. (1987). Studies on the isolation of glucose-6-phosphate dehydrogenase from $A$. nidulans. Journal of the Indian Institute of Sciences 7, 43-46.

Malcolm, A. A. \& ShePHERD, M. G. (1972). Purification and properties of Penicillium glucose-6-phosphate dehydrogenase. Biochemical Journal 128, 817-831.

MatsuoKA, N. (1988). Purification of glucose-6-phosphate dehydrogenase from the sea-urchin Hemicentrotus pulcherrimus. Comparative Biochemistry and Physiology 89B, 517-520.

Muiño-Blanco, T., Cébrian-PÉrez, J. A. \& Pérez-Martos, A. (1983) Regulation of the oxidative phase of the pentose phosphate pathway in Aspergillus oryzae (Ahlburg). Archives of Microbiology 136, 39-41.

Niehaus, W. G. \& Dil TS, R. P. (1984). Purification of glucose-6phosphate dehydrogenase from Aspergillus parasiticus. Archives of Biochemistry and Biophysics 228, 113-119.

NishikaWA, K. \& KuWANA, H. (1985). Deficiency of glucose-6phosphate dehydrogenase in ace-7 strains of Neurospora crassa. Japanese Journal of Genetics 60, 39-52.

OUCHTERLONY, O. \& NiLSON, L. A. (1978). Immunodiffusion and immuno-electrophoresis. In Handbook of Experimental Immunology, 3rd edn, pp. 1911-1944. Edited by D. M. Wein. Oxford: Blackwell Scientific Publications.

Pontecorvo, G., Roper, J. A., Hemmons, L. M., McDonald, K. D. \& Bufton, A. W. J. (1953). The genetics of A. nidulans. Advances in Genetics 5, 141-239.

Reuter, R., Naumann, M., Güttel, K. \& Hofmann, E. (1986). Interactions of immobilized and free triazine dyes with glucose-6phosphate dehydrogenase from yeast. Biomedica Biochemica Acta 45, 273-280.

RÖBER, B., Stolle, J. \& Reuter, G. (1984). Eigenschaften der Glucose6-phosphat Dehydrogenase aus der SCP Hefe Candida maltosa $H$ Zeitschrift für allgemeine Mikrobiologie 24, 629-636.

ScotT, W. A. \& TATUM, E. L. (1970). Glucose-6-phosphate dehydrogenase and Neurospora morphology. Proceedings of the National Academy Sciences of the United States of America 66, 515-522.

ScotT, W. A. \& MaHonY, E. (1976). Defects of glucose-6-phosphate dehydrogenase and 6-phosphogluconate dehydrogenase in Neurospora and their pleiotropic effects. Current Topics in Cellular Regulation 10, 205-236.

Shaw, C. R. \& Prasat, R. (1970). Starch gel electrophoresis of enzymes. A compilation of recipes. Biochemical Genetics 4, 297-320.

Singh, M., SCrutTon, N. S. \& SCRUTTON, M. C. (1988). NADPH generation in A. nidulans: is the mannitol cycle involved? Journal of General Microbiology 134, 643-654.

UITZETTER, J. H. A. A. (1982). Studies on the carbon metabolism in wild type and mutants of Aspergillus nidulans. Thesis, Agricultural University Wageningen, The Netherlands.

Vincenzini, M. T., Vanni, P., Hanozet, G. M., Parenti, P. \& GUERRITORE, A. (1986). Inactivation and degradation of yeast glucose-6-phosphate dehydrogenase selectively modified by pyridoxal-5-phosphate. Enzyme 36, 239-246. 